\title{
3D Code: Folding in the Architecture of Peter Eisenman
}

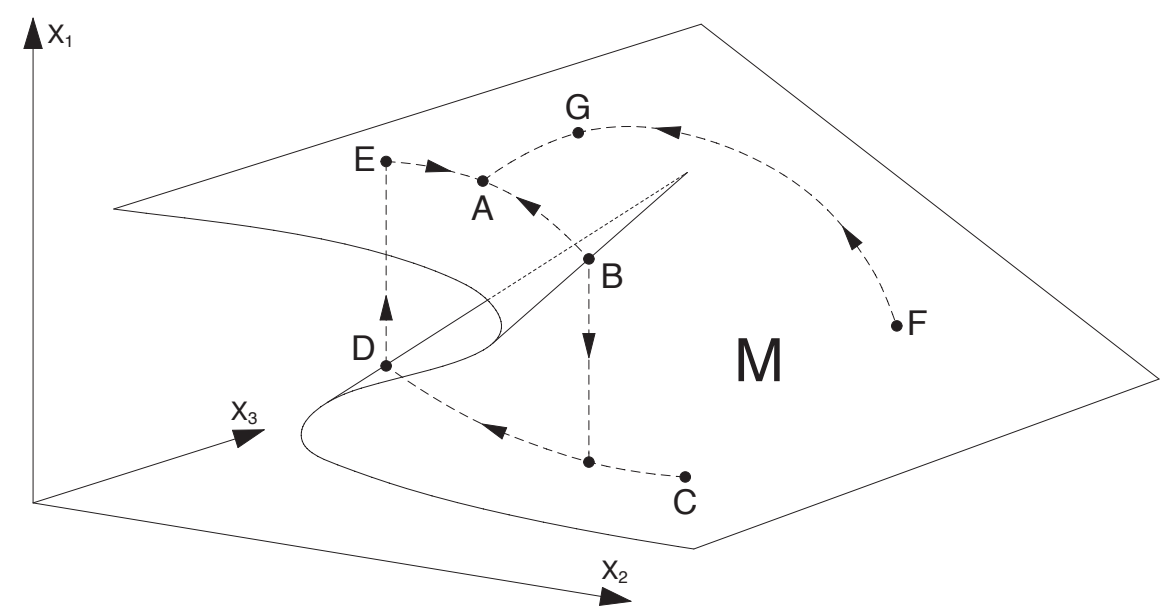

Fig. 1 Chaos theory, René Thom.

"A 'cryptographer' is needed, someone who can at once account for nature and decipher the soul, who can peer into the crannies of matter and read into the folds of the soul."

In the 1990s Peter Eisenman (b. 1932), who since the 1960s has been regarded as one of the most advanced contemporary theorists and practitioners of architecture, developed with the form of the fold a new architectural language based on texts as well as on mathematical models. He supported this with Gilles Deleuze's (1925-1995) book Le Pli (1988), new phenomenology - as presented for instance by Gernot Böhme (b. 1937) in Atmosphäre:

1 Deleuze 1993, 3. 
Essays zur neuen Ästhetik from 1995 - and René Thom's (1923-2002) chaos theory. ${ }^{2}$ For Eisenman the fold is a form that bridges inner and outer worlds, geometry and the description of mental states. At the same time, the fold is able to build on the geometry of the grid as well as on the theories of perception and mathematics. Historically, the fold can be traced back in particular to the metaphysics of Leibniz's Monadology. With the example of the drapery characteristic of the Baroque age, Leibniz (1646-1716) searched beyond systematic rationality for new concepts of singular phenomena, not in the logic of an object, but in accordance with the idea of an "aesthetic, [...] poetic thing." In his Monadology, which has come to be known as a theodicy, Leibniz thus distanced himself from contemporary philosophical currents of atomistic and substance theories. ${ }^{5}$ Rather, he translated the phenomenon of folded cloth into a general concept and linked this to the idea of the universe, which he "describes as a continuous body that is 'not divided, but transfigured in the manner of wax, and folded in various ways like a tunic." "In this way, Baroque drapery as formalized matter was able to avoid the accusation of the mere decoration of the clothed body and, with reference to Aristotle's theory of elements, be transformed into a mental object. As Deleuze notes, Leibniz's metaphysics is based on a conception of the world that is oriented not to Descartes's (1596-1650) unity of the manifold, but to a multiple of the event. Here, the event is materialized in the form of folds, which according to Deleuze are actualized in the soul. In the following, the influence of the theory of monads on Eisenman's architecture will be explored. The argumentation follows on the one hand the logic of the geometry of the fold, which as a Euclidean projection displaces the form of the grid, and on the other the logic of American pragmatism, whose history has given rise to a variety of forms, including, in particular, tensegrity structures. These forms in turn can be interpreted as direct precursors to the fold. To finish, I will examine the theme of the fold's space of representation, which in Eisenman's architecture not only takes account of standards of communication, but also brings about a singular affective space - one that is characteristic of the style of the architectural fold.

\section{Geometry of the Fold}

Eisenman thus takes up the neoplatonic tradition of the theory of monads and transfers the fold onto his architecture. He situates this form, which is so characteristic of his designs of the 1990s, between body and soul, geometry and perception. At the same time, the fold in its genesis draws on the grid as one of the key foundations of architectural design. The fold makes the grid a condition by undertaking on the basis of the gridded surface irreg-

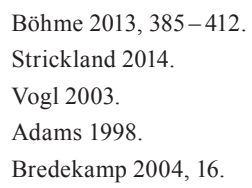


ular, singular displacements of the same. The grid thus becomes the elementary point of reference from which Eisenman simultaneously detaches the fold. These irregular, singular displacements within the grid are articulated by Eisenman with the idea of an architecture of the informe. ${ }^{7}$ Furthermore, Eisenman understands the fold as a connection to the outside resulting from the removal of the distinction between figure and ground. In this connection, Eisenman makes use of language, to in turn with reference to Deleuze describe ex-pli-cation as both concept and action in the process of folding and unfolding. To give the form its own ontological status while simultaneously bypassing the logic of the grid, Eisenman replaces the concept of the grid with that of the frame, which he borrows from a book by his long-term friend Jacques Derrida (1930-2004), The Truth in Painting. ${ }^{8}$ With the frame Derrida examines with the help of the garment and with reference to Immanuel Kant the dichotomy between ergon and parergon in order to explore the difference between an object's in- and extrinsic qualities. Along the division between inside and outside, the frame in this assessment can be perceived as a marking with varying degrees of formalization. Derrida in The Truth in Painting gives the example of columns around a building, with which "is announced the whole problematic of inscription in a milieu, of the marking out of the work in a field of which it is always difficult to decide if it is natural or artificial and, in this latter case, if it is parergon or ergon." "With reference to Derrida, Eisenman develops the image of a subordinate dimension of the folding of the space in which this folding is inserted. According to the philosopher and architectural theorist John Rajchman (b. 1946), this insertion in space can itself be considered as active geometrization, but which in distinction to origami is not reduced to a figure, but incorporates the milieu as part of the folding. This is realized by Eisenman for example in his design for Rebstockpark, in which he crosses over the fixed limits of the site to include what is external to the site in the folding: "The Rebstock fold is thus not only a figural fold as in origami - not a matter simply of folded figures within a free container or frame. Rather the container itself has been folded together, or complicated, with the figures."10

Here, the central question circles around the potential of the peripheral, which has also been touched on by Aby Warburg (1866-1929) with his concept of the "bewegtes Beiwerk" (animated accessory). In this context, Eisenman pursues with the concept of the index taken from linguistics the idea of a potential available to the fold found in the concepts of ex-pli-cation and un-folding. In this way, architecture, understood as text, can be understood as the constitution of the absent. ${ }^{11}$ Here, Eisenman pursues a conceptual thinking with regard to the diagram, which on the basis of the different possibilities of classification and its interstices, moves along the dividing line between order and disorder, complexity

\footnotetext{
7 Eisenman 2007b.

8 Derrida 1987.

9 Derrida 1987, 59.

10 Rajchman 1998, 21.

11 Eisenman 2004a, 299f.
} 
and the reduction of complexity: "The diagram is indeed a chaos, a catastrophe, but it is also a germ of order." $" 12$

The diagram thus offers another approach to Leibniz's metaphysics. If the latter was still characterized by the idea of divisions, Deleuze reverses the idea of unity into that of the multiple: "Classical reason toppled under the force of divergences, incompossibilities, discords, dissonances. But the Baroque represents the ultimate attempt to reconstitute a classical reason by dividing divergences into as many worlds as possible, and by making from incompossibilities as many possible borders between worlds." ${ }^{13}$ With reference to Deleuze's concept of the multiple, Eisenman also clearly disassociates himself from the much-quoted mathematician and architectural theorist Leon Battista Alberti (1404-1472), who in the play with geometries described their functional unfolding. ${ }^{14}$ In contrast to Alberti, who derived all variations of the multiple from the ideal and real grid, Deleuze defines the multiple inversely as a condition of unity: "The multiple is not only what has many parts but also what is folded in many ways." 15 Thus, while Alberti's considerations take unity as their point of departure, for Deleuze there is no finite unity; rather, there are endless possibilities of the multiple in the unfolding. Unlike Alberti therefore, Deleuze's considerations on the fold do not result in a universal model. Neither Cartesian space nor Aristotelian place is accepted into his approach.

\section{The Inclined Plane as Precursor to the Fold}

Eisenman's architecture of the fold, in its concretion, can, however, be traced back to direct precedents, which were initially still characterized by the geometry of the plane. In his manifesto The Oblique Function from 1966, the architect and philosopher Paul Virilio (b. 1932) distances himself from modern architecture insofar as this is based on a separation of functions. ${ }^{16}$ Virilio reverses this principle. Together with the architect Claude Parent (b.1923) he developed at a distance to modernism the form of the inclined plane, which unified functions instead of separating them. Virilio and Parent both derived the form of the inclined plane from their perceptual experiences in bunkers during World War II, which they combined with the concept of a multiplication of life taken from developmental biology, and applied to the spatial layout of their design for Maison Drusch from 1963 near Versailles. ${ }^{17}$ As with a stage, the inclined plane provides a possible space for actions. Hence, at the center of this architecture are not fixed allocations or occupations of place

\footnotetext{
12 Deleuze 2003, 102.

13 Deleuze 1993, 81.

14 Alberti 1454, 16 f.

15 Deleuze 1993, 3.

16 Virilio 1997.

17 Virilio 1997. Cf. also Maak 2010, 20.
} 
and space following a Platonic model, but events linked to time. In comparison, Deleuze alludes in the concept of the event - which he derives from Leibniz's theodicy, ${ }^{18}$ and originally described the demise of God's omnipotence in the modern period - to the loss of hierarchically structured centeredness. ${ }^{19}$

The event is defined with regard to the fold as a phenomenon of decentralism, which in geometrical terms represents a deviation from the regularity of the grid. To understand this better, it is worth looking briefly at the origins of the grid.

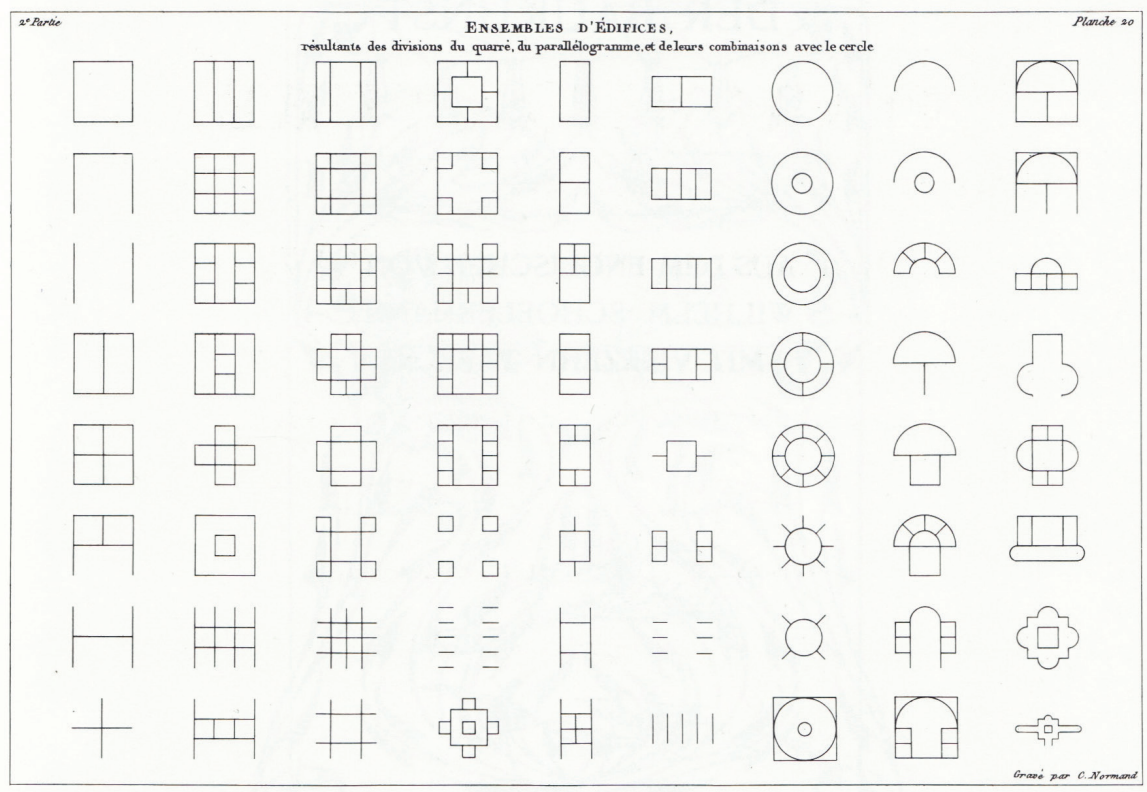

Fig. 2 Ensembles d'édifices, Jean-Nicolas-Louis Durand.

\section{The Origin of the Grid}

In 1803 at the École polytechnique in Paris, the French revolutionary architect Jean-Nicolas-Louis Durand (1760-1834) introduced the schematism of a plan grid in the form of graph paper, which provided the basis for systematic geometrization. Durand used the grid to develop model books for elementary types of functional buildings. ${ }^{20}$ True to militant enlightenment ideas, the clear and evident elements were intended to establish a lasting

18 Leibniz 1978, vols. I-VII.

19 Eisenman 2004b, 235f.

20 Durand 2000. 
architectural language. Indeed, Durand anticipated important parts of the functionalism of the beginning of the $20^{\text {th }}$ century, as well as Ernst Neufert's Bauentwurfslehre. However, not all recipients were pleased with such practices. Gottfried Semper (1803-1879) for example, as a representative of a tendency opposed to neoclassicism, criticized the schematism in Durand's square grid, in which he feared the end of architecture. Durand operated in the spirit of $19^{\text {th }}$ century scientism, in which earlier concepts of experience-based subjective judgment would be replaced by the modern concept of a universal science. Nevertheless, he was not the first to make use of such ideas.

Already 50 years earlier the teaching of geometry had been introduced at the École du Génie de Mézières, which had given rise to the teaching of stonecutting based on drawing. This was characterized by a representation of stone constructions using parallel projection, and thereby represented an application of stereometry. The resulting trait, the term for the production of templates used in cutting the stones, could only be communicated with difficulty, however, and therefore was not able to establish itself as a symbolic language. ${ }^{21}$ In the shift in training from general geometry to a drawing to be produced according to fixed rules, Alois Riedler was able to recognize the new possibilities of such a universal language for engineers and architects. ${ }^{22}$ Just as already in the $18^{\text {th }}$ century the career of the engineer could establish itself with a focus on mathematics, and subsequently the further specialization of engineer and architect made the profession of master builder obsolete, drawing became the most important medium of communication for architect and engineer. Against this background, graph paper gave rise to a particular form of systematic training in drawing, which has another precursor in the techniques and instruments of surveying. ${ }^{23}$

This can be traced back as far as the Romans, who built their streets and cities on the basis of geometric grids. Starting from the division of the sky, which was then projected onto the ground as umbilicus or navel, the Romans determined the cardo and decumanus, the east-west and north-south axes, thereby forming four quadrants. These quadrants were then repeatedly divided until they assumed the dimensions of the floor of the Pantheon. ${ }^{24}$ Besides this form of an idealized division, the quadrants thus obtained also formed the economic units of their calculated administration.

The architectural historian Volker Hoffmann attributes the invention of a net composed of threads to the master builder Filippo Brunelleschi (1377-1446), insofar as he is able to show that the latter measured the topography of ancient Rome with the help of squared paper. ${ }^{25}$ In this way, Brunelleschi affiliates himself in his methodology with the contemporary

\footnotetext{
21 Evans 1995, 179-238.

22 Riedler 1896.

23 Grelon 1994, $15-57$.

24 Sennett 1994, 106-108.

25 Hoffmann 1992, 323f.
} 
astronomer Paolo dal Pozzo Toscanelli (1397-1482), who likewise made use of gridded paper to map constellations, and thereby called on the long tradition of employing grids in cartography since antiquity. In his Trattato di architettura the sculptor, master builder, and theorist Antonio Averlino (1400-1469), known as Filarete, also points out the advantage of squared paper for the securing of true-to-scale representations. ${ }^{26}$

In the art of the Renaissance the grid was subsequently developed for the purpose of faithful depiction in the graphic arts. Even before Dürer's (1471-1528) classic text, the architectural theorist Leon Battista Alberti as well as the painter and polymath Leonardo Da Vinci (1452-1519) made analogous observations with regard to the velum. ${ }^{27}$ In 1528 Albrecht Dürer finally used a velum as the lattice between the draftsman and his model in his woodcut Der Zeichner des liegenden Weibes. Under the influence of Euclid's Elements, Dürer formulated in the Unterweysung der Messung his methods for a systematic training in geometry. ${ }^{28}$

\section{The Dynamization of Geometry}

While Alberti still strove to fix an object in its position in space by means of a velum, as was also suggested by René Descartes in his theory of the distinction between res extensa and res cogitans, in the modern physics of the $20^{\text {th }}$ century at the latest there was a shift in the relation to space and time: time took primacy over the previously fixed metric order of the spatial context. ${ }^{29}$ An intermediary step in this direction was taken by Leibniz with his theory of monads, in which he opposed the mechanistic physics of Descartes, in order with the help of point-like centers of force to formulate a unity of non-material, metaphysical conditions. In this connection, Horst Bredekamp has described Leibniz as a "symbol maker par excellence." 30

If in their beginnings the factors of verifiability and measurability still served an emancipation from the hegemony of theological and aristocratic forms of knowledge and power, then subsequently, as an attempt at universal topological as well as physiological forms of measurement, they represented a new formation of geometrization and disciplining. ${ }^{31}$ Thus, the English philosopher and physician Robert Fludd (1574-1637) - two generations after Leonardo da Vinci - at the beginning of the $17^{\text {th }}$ century searched for modern forms of the measurability and representability of physiological coherences between the outer

\footnotetext{
26 Spencer $1965,315$.

27 Alberti 1435, $16 \mathrm{f}$.

28 Dürer 1538.

29 Koyré 1990.

30 Bredekamp 2004.

31 Galilei 1610. Cf. also Zur Lippe 1974.
} 
world and the inner human. Here, he moved between fully achieved painterly symbol and graphic technical sketch. ${ }^{32}$

\section{American Pragmatism}

The beginnings of a systematic recording of the world were not, however, related only to art and technology, but also to natural phenomena. Around 1900, with his atlases of art forms in nature, in which in the form of symmetries he presented the theory of evolution as a worldview, the zoologist and physician Ernst Haeckel (1834-1919) paved the way for biologism. ${ }^{33}$ With the beginning of the $20^{\text {th }}$ century, a new orientation took place with the mathematician and biologist D'Arcy Wentworth Thompson (1860-1948). In his magnum opus On Growth and Form Thompson examines the influence of mathematics, physics, and mechanics on evolution against the background of thermodynamics. ${ }^{34}$ With his mechanistic explanatory models he assigned, on the basis of mechanics, causal explanatory models to evolutionary morphological changes in form, and thus developed further a Cartesian conception of the world. What concerned him were the ways in which thermodynamics could be transferred to matter, while the immaterial disappeared entirely from possible explanatory approaches. According to Thompson, changes in form comprised both the conception of Cartesian transformations and ideas of morphogenesis.

\section{The Transformation of Tensegrity Structures}

These new models of transformation have been featured by architecture in different forms. Perhaps the most prominent was developed by the engineer and architect Richard Buckminster Fuller (1895-1983) at Black Mountain College, founded in 1933 in North Carolina, USA, which made a name for itself through the program of an equal status of art and science in the service of social responsibility. The reform-pedagogical ideas of the philosopher John Dewey (1859-1952), who at his institute at Black Mountain College focused on experience-based interdisciplinarity, contributed decisively to the formation of the school of functionalism. These ideas should be understood as a consequence of American pragmatism, which after the turn of the century viewed itself as a "Reform Darwinism." 35 With the figures Dewey, William James, and George Herbert Mead, pragmatism was able to enter into a union with functionalism. ${ }^{36}$

\footnotetext{
32 Fludd 1619.

33 Haeckel 1913. Cf. also Breidbach 1998.

34 Thompson 1917.

35 Goldman 1997.

36 Hutterer 1998, 181.
} 
Buckminster Fuller operated in the spirit of an architectural conception mediating between pragmatism and functionalism that is typical especially of the American $20^{\text {th }}$ century. With

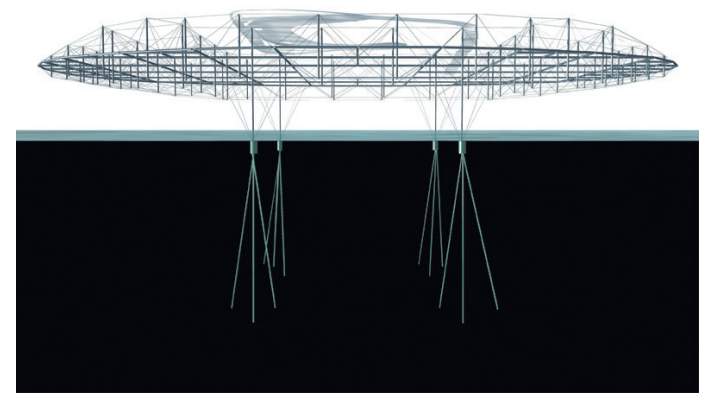

Fig. 3 Blur pavilion, tensegrity structure, computer model, Diller Scofidio + Renfro.

the example of the Blur pavilion by the American architects Elizabeth Diller and Ricardo Scofidio for the Swiss Expo 2002, it can be shown how the technical basis of the pavilion supports the idea of the fleetingness of the image of a cloud.

Here, the transformation of appearance enters into a union with engineering, which can be traced back to Buckminster Fuller's form experiments. While the pavilion as walk-in cloud takes up traditional technical and allegorical theories of space, and stages them anew, its floor is made of a tensegrity construction made of steel tubing with flexible joints and 20,000 mist nozzles. The architects, who decided to work with the surrounding water, which was sprayed in the form of mist by means of a computer-controlled weather system, entirely abandoned the architectural categories of inside and outside. The idea of a skin is replaced by an atmospheric space of experience. The play with the two states of the fluid and the gaseous involved an outer and optically perceivable space of vision as well as an inner and atmospherically experienceable affective space. Interesting in this construction is the pavilion's undulating floor, which as load-bearing system symbolizes the instability that all transformations of the figure contain in themselves. A tensegrity structure as a suspension system made of flexible tension rods formed the technical basis for the aesthetic appearance of this cloud. Its ingenious inner and outer balance in the tradition of American functionalism after Buckminster Fuller followed the logic of an optimized reduction of supporting elements. As lightweight load-bearing structure it could be installed in an uncomplicated way and with a minimal use of materials. On a structural level, stable polyhedra acted as the basic elements for this load-bearing construction. 
Buckminster Fuller took as a starting point a dynamic balance of swaying and interconnected systems, and not a grounded structure. With regard to its dynamic balance of forces, this structure is closely related in a figurative sense, on the one hand, to the model of space-time in modern physics, which abandoned fixed physical quantities and translated them into vectors; on the other, to the aesthetic forms of natural orders such as snowflakes and crystals. ${ }^{37}$ The genealogy of tensegrity is worth at least sketching out. The term is a neologism composed of the terms tension and integrity. The first tensegrity structure was the wire-spoke wheel developed between 1871 and 1876 by James Starley (1830-1881). Thus, when in 1913 Marcel Duchamp mounted a bicycle fork with its wheel on a stool, and presented the result as the first Readymade, he was simultaneously showing an object that was also worth looking at due to the balance of forces contained in it.

The further development of this principle was carried out by Buckminster Fuller and his student, the artist Kenneth Snelson (b. 1927). ${ }^{38}$ Tensegrity structures are characterized by a load-bearing system held in balance by a series of elastically connected tension rods. This dynamic structure gives rise to a form that cannot be described with the idea of groundedness found in traditional architecture. This was demanded by the Roman architect Vitruvius in his De architectura from the $1^{\text {st }}$ century B.C. as one of the defining categories on the basis of the Aristotelian conception of the solid Earth. Since then it has dominated the history of architecture in the form of a rectangle. As Ernst Cassirer has noted, this category, which is based on a fixed concept of space, underwent a transformation at the latest during the Renaissance period with the transition from an Aristotelian to a dynamic conception of the world. Immanuel Kant would then detach this relation from space and dynamize it in the direction of time. ${ }^{39}$ In the $20^{\text {th }}$ century this change is exemplary of the change in the conception of the physical order brought about by Einstein's theory of relativity, which describes the universe as a field consisting of a balance of forces. ${ }^{40}$ During the final years of World War II a number of researchers and engineers began to think over the basic structure of engineering in a model setting. On this basis, Buckminster Fuller became interested in a newly founded, universally valid engineering based on not two- but three-dimensional geometry, in which two lines do not intersect at a point as on paper, but form two linked elements in space with a specific relation of forces. He associated this practical geometry with a particular interpretation of the transitions of the elements described by Plato in Timaeus, the so-called platonic solids. ${ }^{41}$ Among other things, Fuller reconstituted the Platonic solids. He began with a square whose sides were made of rigid struts, but whose corners were made of flexible rubber tubes. This led to astonishing results. Of its own accord the square does not keep its shape, but topples over like a slanting cube.

\footnotetext{
37 Fuller 1982.

38 Snelson 2015.

39 Kant 1786.

40 Cassirer 1956.

41 Fuller 1975. See also Plato 2008, 53e, 54 a-c.
} 
The figure subsequently passes through various states of oscillation; the only stable form here is formed by an isosceles triangle. Hence, it was this rather than the square frame that Fuller designated as the basic element of his building structures. ${ }^{42}$

Through his interest in the geometries of Platonic solids and other original experiments, Buckminster Fuller was alerted to the physically effective structural laws of nature. He subsequently tested his results in empirical experiments on various load-bearing systems. The first of these experiments can be traced back to the early 1940s. However, it was only after World War II that they were given a memorable shape in the practical forms of geodesic cupola and dome, which would eventually make Buckminster Fuller famous. ${ }^{43}$ His constructions were based on a flat and convex or concave space frame, the so-called octet procedure made up of alternating octahedron and tetrahedron cells. ${ }^{44}$

With this transferal of scientifically-oriented model questions and the structure of atomic configurations onto load-bearing systems, Buckminster Fuller was turning in particular against the International Style. In his introduction to Five Architects, Colin Rowe describes the International Style as a reflection on form in the context of economic agendas especially in the USA. ${ }^{45}$ The outer sign of this official direction was a loss of the ideals of European architectural modernism. The related tendency of the reduction of architecture to its form is opposed by the so-called New York Five - to which besides Michael Graves, Charles Gwathmey, John Hejduk, and Richard Meier also Peter Eisenman belonged - with the help of a semiotics derived from linguistics. With the institutionalization of the subject of architectural theory and the application of semiotics to architecture in accordance with the linguistic turn diagnosed by Gustav Bergmann and Richard Rorty, the New York Five searched for new, more open interpretative models. ${ }^{46}$

Unlike his colleagues, however, Fuller focused in his considerations less on explicit linguistic models than on calculation and empiricism by means of mathematics and practical geometry. In his material-based transformation studies he discovered that the geometrical derivation of Platonic solids could be reduced, starting with a cuboctahedron via an icosahedron to an octahedron, and finally via the fold and inversion, to a triangle. This is the minimal, irreducible unit of every structurally relevant construction: "the triangle is a model in which each side stabilizes the opposite angle with a minimum of effort." ${ }^{47}$ In space

42 Snyder 1980, 115.

43 The inventor of the geodesic dome in lightweight construction is thought to be Walther Bauersfeld with his Zeiss Planetarium in Jena (1919-1926). Unlike Buckminster Fuller, however, Bauersfeld did not have his dome patented.

44 Krausse 2002, 42.

45 Rowe 1975.

46 Rorty 1967.

47 Snyder 1980, 117. 
this corresponds to a tetrahedron. This principle thus replaces the traditional framework based on a square. As a so-called four-bar frame the latter was still used for example by the Stuttgart architect Frei Otto, who was likewise oriented to bionics. In 1972, as director of the Institut für freitragende Flächenbauwerke, Otto built the Olympic stadium in Munich with its spectacular roof. ${ }^{48}$

Buckminster Fuller thus categorically rejected the previous orientation to the square. With his triangles and by deploying projective geometry, he attempted to propose an alternative to the Cartesian coordinate system and to Euclidian space. With his focus on three-dimensional processes as opposed to planar geometry, Buckminster Fuller transferred the Greek idea of the close disposition of spatiotemporally bound forms - such as the ichnographia (plan), orthographia (elevation), and scenographia (perspective) - to a dynamically conceived system model. For this he used sketches in the form of vector plans, which did not, however, entail the disengagement from every kind of illusionism to the benefit of an idea of timelessness. Rather, Fuller drew on modern spatial concepts of physics, such as Erwin Schrödinger's space-time structure and Albert Einstein's search for a model for relativity theory. ${ }^{49}$ For this, Buckminster Fuller coined the term synergetics, which he used to launch the idea of an energetic geometry ${ }^{50}$ From this he derived the idea of a structure model, with which as a side note he reformed crystallography. ${ }^{51}$

Buckminster Fuller did not, however, limit himself to the engagement with projective geometry; he also placed this in relation to a visual as well as tactile space of experience. ${ }^{52}$ His embrace of the structural laws of nature in connection with an actively participating subject in dance marks him out as a realist. In other words: the spiritual participation of external realities shifts to the center of Fuller's aesthetic, which distinguishes him from a nominalist, who is concerned with mere orders of nature. Accordingly, his classes at Black Mountain College in North Carolina did not foreground fixed typologies, but taught according to the principle of how nature itself builds. Unfortunately, the question of which nature is being referred to here is not fully answered. As is known, the concept of nature does not arise from a reception, but is the result of an active construction..$^{53}$ Buckminster

48 Nerdinger 2005.

49 Einstein 1923.

50 Snyder 1980, 135.

51 Fuller could demonstrate that there is a five-fold symmetry, which had previously been strictly rejected by representatives of crystallography. "It was Fuller's Expo-Dome, which Kroto and Smalley had seen in 1967 in Montreal, which posited them on the right track. Architecture as a catalyst of a scientific knowledge? Why not - especially when such a case of pattern recognition repeatedly occurred. The first catalysis of this type took place during 1959-62, as Donald Caspar and Aaron Klug [Nobel Prize in Chemistry, 1982] discussed with Fuller the structure of the viruscapsid." In: Krausse 2000, 211 (trans. by S. S.).

52 Buckminster Fuller called his series of experiments with Platonic solids, which he staged with one model, "five ways to dance the Jitterbug." Krausse 2002, 40 - 49, cf. also id. 1998, 293 -294.

53 Haag 1973. 
Fuller's concern therefore was to convey a method of acquiring an empirically based structural knowledge. The logic of this was not exhausted in the mimetic imitation of natural structures; it also lay in the anticipation of the ideal forms of a practical artist-engineer. ${ }^{54}$

\section{Renaissance of Pragmatism}

If American functionalists in the first half of the $20^{\text {th }}$ century focused on the idea of an evolutionary life process and an adaptation to the environment, which they tested out above all in experiments, then the protagonists of poststructuralism, Jacques Derrida and Gilles Deleuze among others, were concerned with a language-centered engagement with theory. This tendency, which arose out of linguistics, led to the establishment of the subjects of architectural history and theory at the ETH Zürich by Bernhard Hoesli in 1967 as well as at the Institute for Architecture and Urban Studies founded at the same time by Peter Eisenman in New York. ${ }^{55}$ In this context, the launching of Eisenman's publications Oppositions and Skyline also made an essential contribution to an autonomization of architecture via the detour of language. ${ }^{56}$ Subsequently, Eisenman developed the idea of architecture as an intertextual system, which in the 1980s he gradually expanded with concepts and methods derived from generative grammar after Chomsky, as well as from phenomenology and philosophy. ${ }^{57}$ In this way, Eisenman can be seen as a direct successor to the English architectural theorist Colin Rowe, who in the immediate postwar period formulated an architecture as a self-referential system of signs characterized by trans-temporalities and structural thought, which permitted cross-references between Andrea Palladio and Le Corbusier. In this connection, Eisenman became among other things a model for the artist-architect Gordon Matta-Clark, whose projects tested new formats both on paper and in space. ${ }^{58}$

\section{Architecture of the Event}

In the 1990s Eisenman turned his attention to an architecture of the philosophy of the event. This is characterized by a relation between inside and outside, as described by Deleuze in

54 "I did not copy nature's structural patterns. I did not make arbitrary arrangements for superficial reasons. What really interests me therefore in all these recent geodesic tensegrity findings in nature is that they apparently confirm that I have found the coordinate mathematical system employed in nature's structuring. I began to explore structure and develop it in pure mathematical principle out of which the patterns emerged in pure principle and developed themselves in pure principle. I then realized those developed structural principles as physical forms, and in due course applied them to practical tasks.” In: Fuller 1964, 59.

55 Frampton/Latour 1980, 5-41.

56 Eisenman 2004a, 227-231.

57 Eisenman 2005, 224.

58 Ursprung 2012, 38f. 
the figure of the rhizome. ${ }^{59}$ Instead of fixed hierarchical attributions of positions in space and place, the rhizome takes up the tradition of Leibniz's theodicy. ${ }^{60}$ In this context, with regard to the increase of complexities and manifolds as opposed to the essences in Plato, Joseph Vogl formulates the essential difference between Leibniz and Deleuze: "Rather than a question about the essence, we are presented with a polyphony of questions relating to the accident, to the manifold, and to the event." 61

If Buckminster Fuller's tensegrity structures were still governed by the systematics of transformation on the basis of platonic solids, Eisenman follows in his transformations the logic of the philosophy of the event characterized by singularity. At the same time, with the shift from intertextuality to folding, one can discern a renaissance of pragmatism. However, unlike the pragmatists of the turn of the century who were concerned with biologistic models, Eisenman refers to a machine model, at whose basis, according to Horst Bredekamp, one can also discern the imitation of nature. ${ }^{62}$

It is not by chance therefore that Eisenman drew on mathematical models, especially those of René Thom, whose chaos theory deals with dynamic types. Here, Thom examined dynamic systems ${ }^{63}$ with regard to their qualitative changes resulting from volatility. ${ }^{64} \mathrm{As}$ with all mathematical problems, Thom was concerned with the abstract modeling of the real world. More precisely, he was engaged with the description of the border zones of fractals in chaos theory. Here, mathematical catastrophe is described as an abrupt change of state leading to folds: "In the three-dimensional diagram of such a nonlinear, discontinuous system one recognizes in the critical threshold of a sudden change of state a folding of the diagram, which is also described as a catastrophe." ${ }^{65}$

In the mathematical model of chaos theory Thom distinguishes the forms cusp, swallowtail, butterfly, wigwam, elliptic umbilic, hyperbolic umbilic, parabolic umbilic, symbolic umbilic, and fold. ${ }^{66}$

59 Deleuze/Guattari 1987, 4-25.

60 Leibniz 2013.

61 Vog1 2003.

62 Bredekamp 1995.

63 Thom 1975, chapters 4, 5. Cf. also Aubin 2004, 95-130 and Aubin 2001, 255-279.

64 Zimmermann 1980, 385.

65 Werner 1996, 85.

66 Zimmermann 1980, 385-412. 


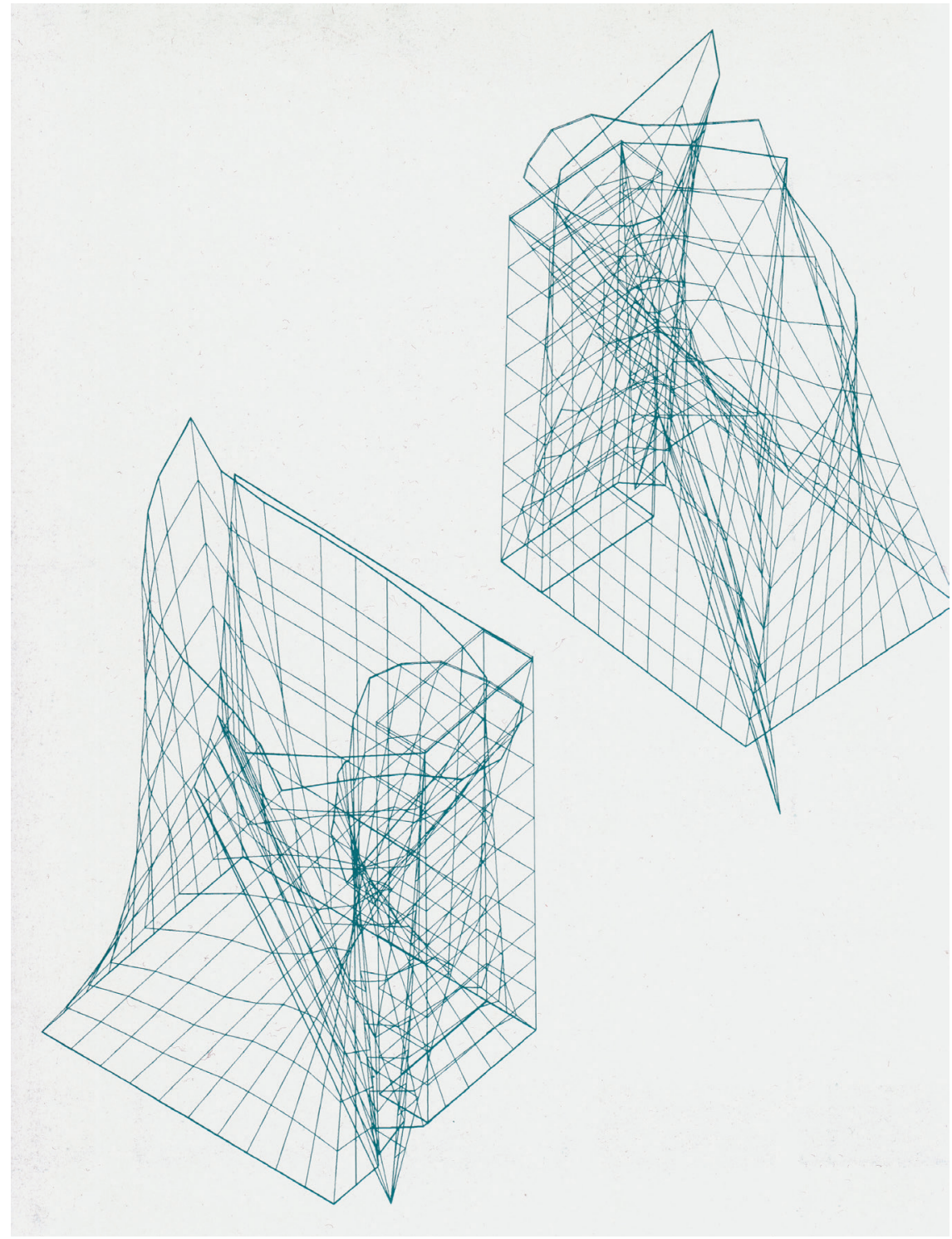

Fig. 4 Design for Haus Immendorff, Peter Eisenman.

As a source for his design for Haus Immendorff from 1993, Eisenman made use of Thom's model of the soliton wave, which represents an example of physical self-organization characterized by nonlinearity. The function of linearity is replaced here by curves and refractions. In this relation, Thom mentions both the Mandelbrot set and the Koch snowflake. 
"The fold as a technique in architecture can accomplish opposite qualities: it can represent a sudden change of direction, assumption, or mood [...] Conversely it can resolve differences in a way which is distinct from the other architectural methods of dealing with pluralism, such as collage. This is by enfolding, by connecting that which is different in a smooth transition. Here suppleness and smoothness are important - the way, for instance, that two different liquids are enfolded into each other by stirring." ${ }^{67}$

In these formalizations folding is thus attributed the function of dynamic changes that are not only of use for purposes of communication, but also become transferrable entirely in the spirit of the modern sciences. ${ }^{68}$ At this point it can also be surmised why Eisenman saw in chaos theory new possibilities for architecture. ${ }^{69}$ With the use of mathematical models he promised himself a way out of the cul-de-sac of postmodernism, which while stimulating architectural discourse, tended formally to be geared to the combination and repetition of form. Against repetition, mathematical models of singular phenomena promised new approaches to architecture.

\section{Forms of Representation}

In modern mathematics once can distinguish among other things three different forms of representation, which Gert Höfner has characterized as follows: ${ }^{70}$ analytic representation - that is, representation through formulae - enables the precise calculation of function values at the expense of the possibility of visualization; graphic representation - that is, representation in the Cartesian coordinate system - which has the advantage of the possibility of visualization, but the disadvantage of less exact values dependent on the increase of the area presented; finally, tabular representation or a table of values, which does not necessitate numerical calculation, but as a result need not display any values. ${ }^{71}$ The missing links between mathematical exactness and visualization articulated in these models therefore no longer allows a transfer of the mathematical model between abstract formulae and real representation. This can be traced back to the founder of analytic geometry, René Descartes who provided the basis for the calculation of geometrical problems by forfeiting the possibility of visualization. ${ }^{72}$ Against

67 Jencks 1995, 53f.

68 Eisenman 2007d.

69 Eisenman 2004b, 235f.

70 Höfner 2015.

71 Among other uses of models in modern mathematics, one should mention model theory, which was first developed in the 1930s, as well as physical models (made from card, string, plaster, and wood, etc.), which were abundant in Europe and in the USA, especially in the $19^{\text {th }}$ century. Cf. Mehrtens 2004, 276-306.

72 Descartes 1637. 
this background, also the enforcement of the graphic representation of spatial structures can be designated as a model, which can also be described as a function diagram with three variables, and which function as orthonormal coordinate system. Complex dynamic systems are here designated as a folding of determining functions. Thus, differential geometry as a mathematical symbol system is able to replace the model of the Euclidean system. In this connection, the new spatial model of the rhizome also gains in importance, which takes the place of a centralized world model, and can be traced back to the beginnings of modern physics. At the beginning of the $20^{\text {th }}$ century the mathematician Henri Poincaré explained the fundamental difference between what rests on measurement - that is, on the haptic - and projective Euclidean geometry. ${ }^{73}$ This distinction brought about new approaches to geometry for use in architectural representation. In the 1980s the architectural theorist Robin Evans (1944-1993) referred to Poincaré, and saw the possibility of considering active as opposed to passive geometries as fields of force in the interstices of conventional gestalt theories. Evans remarked that geometrical composition loses its significance when it is not considered as a tool of projection, which he qualified as projection, quasi projection, and pseudo projection. According to Evans, the tools of these projection types provided new possibilities, as now the fourth, that is, temporal, dimension could be included in the architectural representation. Significant in this context are the so-called fields of force of drawing, which provide the key for the handling of geometries. Within this theory the fold assumes a paradigmatic meaning of a vector-derived geometry that cannot be sufficiently grasped using the figure-ground relation of gestalt theory. ${ }^{74}$ In this logic, Eisenman demands for the representation of his folding architecture, beyond the typical architectural parallel projection of plan, elevation, and section, a topological model in which the index assumes the significance of the reference structure. Here, the index can indicate an unseen or virtual movement. Thus, Deleuze understands the index no longer as map with the reference to the grid, but as schema.

\section{Perceptual Space}

The aspect of reference at the basis of the schema reveals a further approach to the fold, which according to Deleuze can "read into [...] the soul."75

In turning away from the stylistic pluralism of postmodernism, Eisenman draws attention, besides the engagement with geometries of the fold, to an event, which in the Kantian sense lies "before the synthesis of perception." "I In this way, perception becomes an elementary point of reference in Eisenman's architecture: "perception alone dislocates the knowing subject." 77

\footnotetext{
73 Poincaré 1921.

74 Eisenman 2005, 226.

75 Deleuze 1993, 3.

76 Vogl 2003.

77 Eisenman 2007c, 41.
} 
Here, Eisenman understands space not as a precondition of perception in the Kantian sense, but as an atmosphere linked to time. Because in the neopragmatism of postwar architecture the end of theory was evoked and a greater autonomy and engagement with everyday culture was expected of architecture, one rediscovered theories of perception stretching back to the $18^{\text {th }}$ century. Eisenman, alongside other theory-forming protagonists of architecture, can draw on the principles of gestalt theory and, with reference to an active geometry, demands its transgression in order to attain the category of a temporally determined atmospheric space:

“[F]olded space articulates a new relationship between vertical and horizontal, figure and ground, inside and out - all structures articulated by traditional vision. Unlike the space of classical vision, the idea of folded space denies framing in favor of a temporal modulation. The fold no longer privileges planimetric projection; instead there is a variable curvature. [...] [F] olding [...], in terms of traditional vision, [...] contains a quality of the unseen. Folding changes the traditional space of vision. That is, it can be considered to be effective; it functions, it shelters, it is meaningful, it frames, it is aesthetic. Folding also constitutes a move from $e$ ffective to $a$ ffective space." 78

\section{Atmospheres}

The inside-outside relation, which in Eisenman's architecture replaces the concept of the grid with that of the frame, becomes further charged in the context of theories of the event. With affective space, Eisenman wants to bring a modern consciousness to his formal justification. ${ }^{79}$ Eisenman makes explicit reference to the architect Claude Perrault (1613-1688), who is considered Vitruvius's most important translator into French, and in the theoretical dispute with François Blondel demanded a rejection of an aesthetics of nature in favor of temporal concepts of beauty. Eisenman follows this tradition by extending the network of references in the design process beyond scientific standardization and timeless aesthetics to include the instabilities of chaos theory as well as references to fiction and psychoanalysis. In this way, temporal conditions come to the fore, which are not grasped with the concept of type, but rather with that of the topos. ${ }^{80}$ With this approach Eisenman, drawing on phenomenology, also questions the duality of a subject-object relation as well as spatial preconditions in favor of experiences of the event. For Eisenman, this characterizes the modern consciousness. ${ }^{81}$

\footnotetext{
78 Eisenman 2005, 38.

79 Eisenman 2007a.

80 Eisenman 2004b, 236-237.

81 Schwarz 1995, 25.
} 


\section{Projective Space}

Beyond this, the new consciousness is treated by Eisenman as a genuine architectural problem of representation. With a focus on a polymorphic perception, he projects the new consciousness onto a new space of representation. Drawing on Erwin Panofsky, ${ }^{82}$ who in his theory treated perspective not as a mathematical but as a symbolic construction, Eisenman hoped from the fold for a new space of representation. Just as Evans questioned the cultural conventions of Durand's drawing systematics and situated drawing not only in relation to its episteme between drawing and calculating, but also claimed play as a quantity beyond calculability, Eisenman wants to explore the expressive possibilities of the polymorphic perception of form:

\footnotetext{
"Whence the question: how can one return from this perception fashioned by culture to the 'brute' or 'wild' perception? What does the informing consist in? By what act does one undo it (return to the phenomenal, to the 'vertical' world, to lived experience)?" 83
}

In this way, Eisenman acts in analogy to the painters of the time of Alberti, the so-called patron of projection - painters who missed in perspective the reflection of human perceptions and therefore categorically rejected the standards of drawing conventions, while in the architecture of the period the form of symmetry ${ }^{84}$ and a correlation between architectural plan and built space prevailed. ${ }^{85}$ Hierarchically centered symmetries following the logic of surveying in cartography have remained in use up to the present as a standard of architectural drawing. They refer back to Euclidean space, which is equated with the sense of touch. In the history of architectural theory, in contrast, the space of vision is associated with projective geometry. In the conflict between Euclidean and projective space Einstein defended Euclidean space by ascribing to it three subcategories: besides Euclidean, he also names Riemannian spherical and stereographic perspectival geometries. According to Evans, he thereby avoided the logic of duality by combining in his theory a field of anamorphic vision consisting of a balance of forces and a Euclidean metric. Within this theory he situated the sense of sight between geometry and visualization, between sensations, motor activities, and concepts. ${ }^{86}$ In this way, perceptions and interpretations are raised to the highest principle, and the shaping of perception is opposed to a "petrified Platonism." Evans, who in his engagement with architectural drawing analyzes the advance of ideas about images, can therefore link geometry via the representation of ideal forms in Greek

\footnotetext{
82 Panofsky 1991.

83 Maurice Merleau-Ponty quoted in Schwarz 1995, 11.

84 Philipp 2007, 147-157.

85 Eisenman 2007d.

86 Evans 1995, 352.
} 
geometry to the manipulation of ideal forms in the geometry of Descartes, and finally to modern models of knowledge.

Here projection becomes central for questions about constructions of the world, whose communication rests on the visualization of graphic representations of knowledge.

Thus, with modern physics conventional assumptions about representation are questioned. ${ }^{87}$ Not representation but the affect placed before perception becomes the focus of the formalization of knowledge. If during the Renaissance a decisive role was played by relations of similarity in the framework of a creation theology, then Descartes translated these into that of a visualization strategy, although he was aware of the distinction between perception and information processing. Descartes differentiated between understanding and sensory perception. ${ }^{88}$ Knowledge about the interactions between conceptual and perceptual space highlights the significance of the formalization of the design process for consciousness and vice versa: "Imagination is not held within the mind, but is potentially active in all the areas of transition from persons to objects or pictures. It operates, in other words, in the same zones as projection and its metaphors." 89

Starting from a modern consciousness, which Eisenman refers to via the detour of philosophy, Euclidian space in the categories developed by Einstein seems only partly suitable for the construction of the fold. Irregular, singular displacements of the grid simultaneously lead to a topology, or put differently a correlation to the diagram, which through its interstices always also factors in the conceptual space of spatially ordered information. In the framework of semiotics, already Charles Sanders Peirce saw in the diagram the possibility of the visualization of thought in general guaranteed. ${ }^{90}$

The fold in Eisenman's architecture thus moves between Euclidean and topological diagrammatic geometry on the one hand, and affective space on the other. It arises as a consequence of the pluralism of postmodernism and is initially a development of neopragmatism, to finally fulfill, with the concept of affect, architecture's claim to autonomy and singularity. Hence, the fold is a form that on the basis of the grid arises through singular displacements, and is concerned not with combinations of forms as in postmodernism, but with experience-based multiperspectivity. In this way, the form of the fold brings scientific models to bear, without, however, relinquishing the space of singular perception that the event, which since Deleuze is unavoidably linked to the fold, first delivers.

87 Eisenman 1995, 582.

88 Descartes 1641, 21.

89 Evans 1995, 363.

90 Peirce 1983. 


\section{Bibliography}

Adams, Robert M. (1998): Leibniz: Determinist, Theist, Idealist. Oxford: Oxford University Press.

Alberti, Leon Battista (1435): Della Pittura. Über die Malkunst. Ed. by Gianfreda, Sandra/ Bätschmann, Oskar (Hg.). Darmstadt: Wissenschaftliche Buchgesellschaft 2002.

Alberti, Leon Battista (1454): De re aedificatoria. Zehn Bücher über die Baukunst. Ed. by Theuer, Max. Wien/Leipzig: Heller 1991.

Aubin, David (2001): From Catastrophe to Chaos: The Modeling Practices of Applied Topologists. In: Bottazzini, Umberto/Dahan-Dalmédico, Amy (eds.): Changing Images in Mathematics: From the French Revolution to the New Millennium. London: Routledge, pp. $255-279$.

Aubin, David (2004): Forms of Explanation in the Catastrophe Theory of Rene Thom: Topology, Morphogenesis, and Structuralism. In: Wise, M. Norton (ed.): Growing Explanations: Historical Perspective on the Sciences of Complexity. Durham: Duke University Press, pp. $95-130$.

Böhme, Gernot (2013): Atmosphäre: Essays zur neuen Ästhetik. Berlin: Suhrkamp Verlag.

Bredekamp, Horst (1995): The Lure of Antiquity and the Cult of the Machine: The

Kunstkammer and the Evolution of Nature, Art and Technology. Princeton: M. Wiener Publishers.

Bredekamp, Horst (2004): Die Fenster der Monade: Gottfried Wilhelm Leibniz' Theater der Natur und Kunst. Berlin: Akademie Verlag.

Breidbach, Olaf (1998): Ernst Haeckel: Kunstformen der Natur. Munich: Prestel.

Cassirer, Ernst (1956): Die Begriffsform im mythischen Denken. In: id.: Wesen und Wirkung des Symbolbegriffs. Darmstadt: Wissenschaftliche Buchgesellschaft, pp. 1-70.

Deleuze, Gilles (1993): The Fold: Leibniz and the Baroque. Trans. by Conley, Tom. London: The Athlone Press.

Deleuze, Gilles/Guattari, Félix (1987): Introduction: Rhizome. In: id.: A thousand Plateaus: Capitalism and Schizophrenia. Trans. by Massumi, Brian. Minneapolis/London: University of Minnesota Press, pp. 1-25.

Derrida, Jacques (1987): The Truth in Painting. Trans. by Bennington, Geoffrey/McLeod, Ian. Chicago: The University of Chicago Press.

Descartes, René (1637): La Géométrie. Dover: Dover Publications 2012.

Descartes, René (1641): Meditations on First Philosophy with Selections from the Objections and Replies. Ed. by: Cottingham, John. Cambridge et al.: Cambridge University Press 2015.

Durand, Jean Nicolas Louis (2000): Précis of the Lectures on Architecture with Graphic Portion of the Lectures on Architecture. Los Angeles, CA: Getty Research Institute. 
Dürer, Albrecht (1538): Underweysung der Messung, mit dem Zirckel un richtscheyt, in Linien, Ebnen und gantzen Corporen. Nuremberg: Hieronymus formschneyder.

Einstein, Albert (1923): The Meaning of Relativity: Four Lectures Delivered at Princeton University, May, 1921. Princeton: Princeton University Press.

Eisenman, Peter (1995): Aura und Exzeß: Zur Überwindung der Metaphysik der Architektur. Ed. by Schwarz, Ullrich. Vienna: Passagen Verlag.

Eisenman, Peter (2004a): Architecture as a Second Language: The Texts of Between. In: id.: Inside Out: Selected Writings, 1963 -1998. New Haven/London: Yale University Press, pp. $226-233$.

Eisenman, Peter (2004b): Blue Line Text. In: id.: Inside Out: Selected Writings, 1963-1998. New Haven/London: Yale University Press, pp. 234-237.

Eisenman, Peter (2005): Ins Leere geschrieben: Schriften \& Interviews 2. Ed. by Engelmann, Peter. Vienna: Passagen Verlag.

Eisenman, Peter (2007a): The Affects of Singularity. In: id.: Written into the Void. New Haven/London: Yale University Press, pp. 19-24.

Eisenman, Peter (2007b): Presentness and the Being-Only-Once of Architecture. In: id.: Written into the Void. New Haven/London: Yale University Press, pp. $42-49$.

Eisenman, Peter (2007c): Visions Unfolding: Architecture in the Age of Electronic Media. In: id.: Written into the Void. New Haven/London: Yale University Press, pp. 34-41.

Eisenman, Peter (2007d): Processes of the Interstitial: Notes on Zaera-Polos's Idea of the Machinic. In: Written into the Void. New Haven/London: Yale University Press, pp. 50-71.

Evans, Robin (1995): The Projective Cast: Architecture and its Three Geometries. Cambridge, MA/London: The MIT Press.

Fludd, Robert (1619): Microscosmi historia. Tomus secundus de supernaturali, naturali, praeternaturali et contranaturali microcosmi historia intractatus tres distributa. Oppenheim: Johann Theodor de Bry.

Frampton, Kenneth/Latour, Alessandra (1980): Notes on American Architectural Education. In: Lotus International, vol.27, no. 2, pp. 5-39.

Fuller, Richard Buckminster (1964): World Design Initiative. In: id.: World Design Science Decade, phase 1, document 2, The design initiative. Ed. by: McHale, John. Carbondale, Illinois: World Resources Inventory, Southern Illinois Univ., pp. 1-104.

Fuller, Richard Buckminster (1982): Synergetics: Explorations in the Geometry of Thinking. New York: Macmillan.

Galilei, Galileo (1610): Die Vermessung der Hölle. In: id.: Sidereus Nuncius, Nachricht von neuen Sternen. Ed. by Blumenberg, Hans. Frankfurt a. M.: Suhrkamp Verlag 1980, pp. 231-250.

Goldman, Eric F. (1997): Rendezvous with Destiny: A History of Modern American Reform. New York: Vintage Books. 
Grelon, André (1994): Von den Ingenieuren des Königs zu den Technologien des

21. Jahrhunderts: Die Ausbildung der Ingenieure in Frankreich. In: id. (ed.): Ingenieure in Frankreich, 1747-1990. Frankfurt a. M.: Campus, pp. 15-57.

Haag, Karlheinz (1973): Der Fortschritt in der Philosophie. Frankfurt a. M.: Suhrkamp Verlag.

Haeckel, Ernst (1913): Die Natur als Künstlerin. Ed. by Goerke, Franz. Berlin: Vita Deutsches Verlagshaus.

Hoffmann, Volker (1992): Filippo Brunelleschi: Kuppelbau und Perspektive. In: Bozzoni, Corrado/Carbonara, Giovanni/Villetti, Gabriella (eds.): Saggi in onore di Renato Bonelli: Quaderni dell'istituto di storia dell'architettura. Rome: Multigrafica Editrice, pp.317-327.

Höfner, Gert (2015): Mathematik im Millimeterpapier. Letter from July 20.

Hutterer, Robert (1998): Das Paradigma der Humanistischen Psychologie: Entwicklung, Ideengeschichte und Produktivität. Vienna/New York: Springer Verlag.

Jencks, Charles (1995): The Architecture of the Jumping Universe. New York: Academy Editions.

Kant, Immanuel (1786): Metaphysische Anfangsgründe der Naturwissenschaft. Riga: Hartknoch.

Koyré, Alexandre (1990): From the Closed World to the Infinite Universe. Baltimore/London: The Johns Hopkins Press.

Krausse, Joachim (1998): Buckminster Fullers Vorschule. In: Fuller, Richard Buckminster: Bedienungsanleitung für das Raumschiff Erde und andere Schriften. Ed. by Krausse, Joachim. Amsterdam/Dresden: Verlag der Kunst, pp. 213-306.

Krausse, Joachim (2000): Das Zwinkern der Winkel. In: Fecht, Tom/Kamper, Dietmar (eds.): Umzug ins Offene: Vier Versuche über den Raum. Vienna/New York: Springer, pp. 187-214.

Krausse, Joachim (2002): Buckminster Fullers Modellierung der Natur. In: Arch+, vol. $159-160$, pp. $40-49$.

Leibniz, Gottfried Wilhelm (2013): Philosophische Schriften: Die Theodizee von der Güte Gottes, der Freiheit des Menschen und dem Ursprung des Übels, vol.2. Ed. by Herring, Herbert. Darmstadt: WBG.

Leibniz, Gottfried Wilhelm (1978): Die philosophischen Schriften. Ed. by Gerhardt, Carl Immanuel, vols. I-VII. Berlin: Olms.

Maak, Niklas (2010): Architekt Claude Parent: Auf der schiefen Bahn. In: Frankfurter Allgemeine Sonntagszeitung, no. 30, 1 August, p. 20.

Mehrtens, Herbert (2004): Mathematical Models. In: de Chadarevian, Soraya/Hopwood, Nick (eds.): Models: The Third Dimension of Science. Stanford, CA: Stanford University Press, pp. 276-306. 
Nerdinger, Winfried (ed.) (2005): Frei Otto: Complete Works: Lightweight Construction, Natural Design. Basel: Birkhäuser Verlag.

Panofsky, Erwin (1991): Perspective as Symbolic Form. Trans. by Wood, Christopher S. New York: Zone Books.

Peirce, Charles S. (1983): Phänomen und Logik der Zeichen. Ed. and trans. by Pape, Helmut. Frankfurt a. M.: Suhrkamp.

Philipp, Klaus Jan (2007): Die Imagination des Realen: Eine kurze Geschichte der Architekturzeichnung. In: Gleiter, Jörg/Korrek, Norbert/Zimmermann, Gerd (eds.): Die Realität des Imaginären: Architektur und das digitale Bild (10. Internationales Bauhaus-Kolloquium Weimar). Weimar: Schriften der Bauhaus-Universität Weimar, pp. 147-157.

Plato (2008): Timaeus. In: id.: Timaeus and Critias. Trans. by Waterfield, Robin. Oxford: Oxford University Press, pp. 1-100.

Poincaré, Henri (1921): Des fondements de la géometrie. Paris: Etienne Chiron.

Rajchman, John (1998): Folding. In: id.: Constructions. Cambridge, MA/London: The MIT Press, pp. 11-36.

Riedler, Alois (1896): Das Maschinen-Zeichnen: Begründung und Veranschaulichung der sachlich notwendigen zeichnerischen Darstellungen und ihres Zusammenhangs mit der praktischen Ausführung. Berlin: Springer.

Rorty, Richard M. (1967): The Linguistic Turn: Essays in Philosophical Method. Chicago: The University of Chicago Press.

Rowe, Colin (1975): Introduction. In: Eisenman, Peter (ed.): Five Architects: Eisenman, Graves, Gwathmey, Hejduk, Meier. New York: Oxford University Press, pp. $3-8$.

Schwarz, Ullrich (1995): Another look - anOther gaze: Zur Architekturtheorie Peter Eisenmans. In: Eisenman, Peter: Aura und Exzeß: Zur Überwindung der Metaphysik der Architektur. Ed. by Schwarz, Ullrich. Vienna: Passagen Verlag, pp. 11-34.

Sennett, Richard (1994): Flesh and Stone: The Body and the City in Western Civilization. London: Faber and Faber.

Snelson, Kenneth: What is Tensegrity? Online: www.kennethsnelson.net/faqs/faq.htm (last access: 17 December, 2015).

Snyder, Robert (1980): Buckminster Fuller: An Autobiographical Monologue/Scenario. New York: St. Martin's.

Spencer, John R. (ed.) (1965): Filarete's Treatise on Architecture. Volume 1: The Text. New Haven/Connecticut/London: Yale University Press.

Strickland, Lloyd (ed.) (2014): Leibniz's Monadology: A New Translation and Guide. Edinburgh: Edinburgh University Press.

Thom, René (1975): Structural Stability and Morphogenesis: An Outline of a General Theory of Models. Trans. by Fowler, David H.. Reading et al.: W. A. Benjamin. 
Thompson, D'Arcy Wentworth (1917): On Growth and Form. Cambridge: Cambridge University Press.

Ursprung, Philip (2012): Grenzen der Architektur. In: Von Amelunxen, Huberts/Lammert, Angela/Ursprung, Philip (eds.): Gordon Matta-Clark: Moment to Moment: Space. Berlin: Verlag für Moderne Kunst, pp. $29-47$.

Virilio, Paul (1997): The Oblique Function. In: Virilio, Paul/Parent, Claude: Architecture Principe: 1966 and 1996. Trans. by Collins, George. Besançon: Les Éditions de l'Imprimeur, pp. iii-v.

Vogl, Joseph (2003): Was ist ein Ereignis? Lecture given at the Center for Art and Media (ZKM). Karlsruhe, 26 October. Online: http://zkm.de/media/audio/joseph-voglwas-ist-ein-ereignis (last access: 25 January 2016).

Werner, Hilmar (1996): Falten im Leichtbau. In: Arch+, vol. 131, pp. 82-85.

Zimmermann, Rainer (1980): Katastrophentheorie und die Geometrie der Entscheidungen. In: Blätter der DGVFM, vol. 14, no. 3, pp. 385-412.

Zur Lippe, Rudolf (1974): Naturbeherrschung am Menschen, 2 vols. Frankfurt a. M.:

Suhrkamp Verlag.

\section{Credits of Images}

Fig. 1: (C) Lucio Nardi 2015.

Fig. 2: Ungers 1985

Fig. 3: (C) Graphics: Diller Scofidio + Renfro: Computer model for the Blur pavilion, Suisse, 2002.

Fig. 4: Kammer/Hinrichs 1993, 46.

\section{Sandra Schramke}

Email:sandra.schramke@hu-berlin.de

Image Knowledge Gestaltung. An Interdisciplinary Laboratory.

Cluster of Excellence Humboldt-Universität zu Berlin.

Sophienstrasse 22a, 10178 Berlin, Germany.

Licensed under the CC Licence BY-NC-ND 3.0 DE https://creativecommons.org/licenses/by-nc-nd/3.0/de/

This is the author's version of the work. The definitive version was published as "3D Code: Folding in the Architecture of Peter Eisenman” in: Friedman, Michael/Schäffner, Wolfgang (eds.): On Folding. Towards a New Field of Interdisciplinary Research in 2016 by transcript Verlag. The text is posted here by permission of transcript Verlag for personal use only, not for redistribution. 